\title{
Kelayakan Usahatani Padi dan Pengaruhnya Terhadap Pendapatan Petani di Desa Margoluwih Kecamatan Seyegan
}

\author{
Sudrajat \\ Departemen Geografi Lingkungan, Fakultas Geografi, Universitas Gadjah Mada, Indonesia \\ Email Koresponden:sdarajat@ugm.ac.id
}

Direvisi: 2019-11-18. Diterima: 2020-02-21

(C)2020 Fakultas Geografi UGM dan Ikatan Geograf Indonesia (IGI)

\begin{abstract}
Abstrak Kelayakan usahatani secara finansial harus menjadi perhatian yang sangat penting dalam kebijakan pembangunan pertanian. Hal ini terjadi karena kelayakan usahatani menentukan besarnya nilai keuntungan finansial yang diterima petani. Berdasarkan hal tersebut maka penelitian ini dilakukan dengan tujuan: pertama mengetahui kondisi sosial-demografi dan ekonomi petani padi; kedua menganalisis kondisi finansial usahatani padi yang mencakup biaya, penerimaan dan pendapatan atau keuntungan usahatani padi; dan ketiga menganalisis kelayakan usahatani padi dan pengaruhnya terhadap pendapatan petani di Desa Margoluwih Kecamatan Seyegan. Jumlah sampel sebanyak 90 petani yang diambil secara random sampling. Data primer dikumpulkan melalui wawancara terstruktur menggunakan kuesioner, sedangkan data sekunder dikumpulkan dari instatsi pemerintah. Data disajikan dalam bentuk tabel dan dianalisis secara deskriptif kuantitatif. Hasil penelitian menemukan adanya variasi kondisi sosial-ekonomi dan demografi petani, sedangkan hasil analisis finansial menemukan adanya variasi biaya usahatani menurut luas lahan dan variasi penerimaan atau pendapatan menurut perbedaan hasil produksi dan biaya. Sementara itu, berdasarkan analisis kelayakan usahatani padi dengan $\mathrm{R} / \mathrm{C}$ ratio maupun dengan $\mathrm{B} / \mathrm{C}$ ratio menunjukkan bahwa kegiatan usahatani padi masih layak dan secara signifikan nilai kelayakan tersebut berpengaruh positif terhadap pendapatan yang diterima petani.
\end{abstract}

Kata kunci: kelayakan; finansial, usahatani, pendapatan, petani.

Abstract Financial feasibility of farming must be a very important concern in agricultural development policy. This happens because the feasibility of farming determines the value of financial benefits received by farmers. Based on this, this research was conducted with the aim to; firstly knowing the socio-demographic and economic conditions of rice farmers; the second analyzes the financial condition of rice farming which includes the cost, revenue and income or profits from rice farming; and third, analyzing the feasibility of rice farming and its effect on farmers' income in Margoluwih Village of Seyegan District. The total sample of 90 farmers taken by random sampling. Primary data was collected through structured interviews using a questionnaire, while secondary data is collected from government agencies. Data is presented in tabular form and analyzed descriptively quantitatively. The results of the study found variations in the socio-economic and demographic conditions of farmers, whereas the results of financial analysis found variations in farming costs according to land area and variations in revenue or income according to differences in production results and costs. Meanwhile, based on the feasibility analysis of rice farming with $R /$ $C$ ratio and with the B/C ratio shows that rice farming activities are still feasible and significantly the feasibility value has a positive effect on the income received by farmers.

Keywords: feasibility; financial; farming; income; farmers.

\section{PENDAHULUAN}

Pengembangan ekonomi kawasan perdesaan melalui pembangunan pertanian diharapkan mampu meningkatkan kualitas sumber daya petani, produktivitas pertanian dan pendapatan petani, sehingga kesejahteraan petani terus mengalami meningkatan (Soekartawi, 2011; Gustiana, 2015; Pratiwi dkk., 2018). Oleh karena itu, menurut Napitupulu dan Marasi (2000) pembangunan pertanian harus terintegrasi dan tidak bisa dipisahkan dari dua pilar pembangunan pertanian, yaitu pilar pembangunan pertanian primer dan sekunder. Pilar pembangunan pertanian primer merupakan kegiatan usahatani yang menggunakan sarana dan prasarana produksi untuk menghasilkan produk pertanian primer. Pilar pembangunan pertanian sekunder merupakan kegiatan yang berupaya meningkatkan nilai tambah produk pertanian primer melalui agroindustri, beserta distribusi dan perdagangannya. Berdasarkan hal tersebut maka arah kebijakan pembangunan pertanian tidak hanya menekankan peningkatan produk pertanian primer, tetapi juga harus memiliki nilai tambah dari produk pertanian sebagai upaya untuk meningkatkan pendapatan dan kesejahteraan petani (Sajogyo \& Martowijoyo, 2005; Suseno \& Suyatnal, 2007; Muin, 2017).

Untuk meningkatkan hasil produksi pertanian (output) dan nilai tambahnya (Value added) peranan input (lahan, modal, teknologi, tenaga kerja, bibit, obat-obatan dan sarana prasaran pertanian) dalam kegiatan usahatani harus menjadi perhatian utama. Peranan input usahatani bukan saja dilihat keragaman jenis atau ketersediaannya dalam waktu yang tepat, tetapi dapat juga dilihat dari segi efisiensi penggunaan input tersebut oleh para petani dalam melakukan kegiatan usahatani. (Prayoga, 2010; Khai dan Yabe (2011); Palabo 2019). Efisiensi dan ketepatan penggunaan faktor produksi 
akan berkaitan dengan besarnya biaya yang akan dikeluarkan oleh para petani dalam melakukan kegiatan usahatani. Ini berarti semakin tidak efisien dan tidak tepak penggunaanya, maka akan semakin besar biaya usahatani yang harus dikeluarkan petani dan akan terjadi sebaliknya. Ketidakefisienan biaya yang dikeluarkan tersebut pada akhirnya akan mempengaruhi besarnya penerimaan dan pendapatan petani (Tahir dkk., 2010; Nguyen et al, 2012).

Secara finansial biaya usahatani dapat diklasifikasikan menjadi 2 (dua) yaitu: biaya tetap ( fixed cost) dan biaya tidak tetap (variable cost). Biaya tetap umumnya adalah biaya yang relatif tetap jumlahnya, sedangkan biaya tidak tetap atau biaya variabel merupakan biaya yang besar kecilnya sangat tergantung oleh hasil produksi pertanian. Ini berarti semakin besar produksi yang dihasilkan petani dari kegiatan usahataninya, maka akan semakin besar biaya tidak tetap yang harus dikeluarkan (Barokah dkk., (2014); Soekartawi, 2011; Suratiyah, 2015). Berdasarkan hal tersebut maka secara finansial petani harus seefisien mungkin menggunakan biaya produksi yang akan digunakan dalam kegiatan usahataninya, agar kegiatan usahatani tersebut memiliki nilai kelayakan finansial yang menguntungkan.

Analisis kelayakan finansial usahatani yang dilakukan tidak hanya melihat layak atau tidaknya suatu kegiatan usahatani, namun harus dilihat juga saat dioperasionalkan secara rutin dalam rangka mencapai keuntungan yang maksimal untuk waktu yang tidak ditentukan (Umar, (2005). Menurut Syarif (2011) dalam analisis kelayakan finansial suatu usahatani ada beberapa indikator yang perlu diperhatikan yaitu; (1) keuntungan usahatani yang didapatkan dari hasil penjualan produk pertanian setelah dikurangi dengan biaya-biaya yang dikeluarkan petani; (2) payback period adalah suatu periode waktu yang diperlukan untuk menutup kembali pengeluaran usahatani dengan menggunakan aliran kas; dan (3) break event point (BEP) yaitu batas dimana usahatani yang dilakukan dapat memberikan keuntungan atau pada tingkat tidak rugi dan tidak untung.

Sementara itu, menurut Umar (2005); Nurmalina dkk. (2009) kelayakan finansial usahatani sangat dipengaruhi berbagai aspek diantaranya adalah: (1) aspek pasar; yaitu berkaitan dengan kejelasan pasar yang dituju, permintaan, penawaran, harga, program pemasaran dan perkiraan penjualan yang bisa dicapai usahatani; (2) aspek teknis yang berhubungan dengan input (penyediaan) dan output (produksi) seperti keadaan tanah di daerah dan potensinya bagi pembangunan pertanian, ketersediaan air, varietas benih tanaman, pengadaan produksi, potensi dan keinginan penggunaan mekanisasi, pemupukan dan alat kontrol yang diperlukan; (3) aspek manajemen dan hukum berkaitan dengan efektivitas dan efisiensi kegiatan suatu usaha yang dipilih, struktur organisasi yang akan digunakan dan jenis- jenis pekerjaan yang diperlukan, sedangkan aspek hukum diperlukan dengan mempertimbangkan bentuk badan hukum dari badan usaha yang telah dibangunnya; (4) aspek sosial, ekonomi dan budaya berkaitan dengan masyarakat keseluruhan yaitu pemerataan kesempatan kerja dan pengaruh bisnis tersebut terhadap lingkungan sekitar lokasi bisnis, peluang peningkatan pendapatan masyarakat dan budaya masyarakat sekitar; dan (5) aspek lingkungan berkaitangan dengan pengaruh kegiatan usahatani terhadap lingkungan. Kelima aspek tersebut di atas memiliki pengaruh yang bervariasi terhadap kelayakan finansial usahatani yang dilakukan petani. Berdasarkan hal tersebut maka seharusnya petani memahami dan mengerti aspek-aspek tersebut agar kegiatan usahatani yang dilakukannya dapat memberikan keuntungan yang maksimal.

Fenomena ketidakpaham petani dalam menganalisis kelayakan finansial usahatani menurut Supartama dkk., (2013) dan Munizar dkk., (2019) disebabkan karena petani tidak mengetahui cara menghitungnya dan petani hanya sebatas menghitung besarnya biaya dan penerimaan saja. Akibatnya, para petani tidak banyak mempertimbangkan nilai kelayakan finansial usahatani dalam kegiatan usahataninya. Berdasarkan hal tersebut maka penelitian ini dilakukan dengan tujuan; (1) mengetahui kondisi sosialdemografi dan ekonomi petani padi; (2) menganalisis kondisi finansial usahatani padi yang mencakup biaya, penerimaan dan pendapatan atau keuntungan usahatani padi; dan (3) menganalisis kelayakan usahatani padi dan pengaruhnya terhadap pendapatan petani di Desa Margoluwih Kecamatan Seyegan.

\section{METODE PENELITIAN}

Penelitian ini dilakukan di Desa Margoluwih Kecamatan Seyegan Kebupaten Sleman. Data yang dikumpulkan ada dua jenis yaitu data primer dan data sekunder. Data primer dikumpulkan secara langsung dari lapangan melalui wawancara dengan petani menggunakan kuesioner secara terstruktur, sedangkan data sekunder diperoleh dari instansi pemerintah seperti; Badan Pusat Statistik (BPS), kantor desa dan pedukuhan serta instansi pemerintah lainnya.

Populasi dalam penelitian ini adalah petani pemilik lahan sawah yang tinggal di lokasi penelitian dan melakukan kegiatan usahatani secara aktif. Pada tahun 2019 jumlah petani Desa Margoluwih tercatat sebanyak 806 KK yang tersebar di 14 dusun. Jumlah sampel sebanyak 90 petani yang menguasai lahan sawah, baik lahan milik sendiri maupun bukan milik sendiri. Jumlah petani dari setiap dusun diambil secara proposional, sedangkan pengambilan responden di lapangan secara random sampling (Tabel 1). 
Tabel 1. Persebaran Jumlah Sampel dari Setiap Dusun di Desa Margoluwih

\begin{tabular}{lll}
\hline Nama Dusun & Jumlah Petani & Jumlah Sampel \\
\hline Kliyo & 61 & 7 \\
Klangkapan 1 & 35 & 4 \\
Klangkapan II & 101 & 11 \\
Klaci I & 80 & 9 \\
Klaci II & 30 & 3 \\
Klaci III & 40 & 4 \\
Barak I & 74 & 8 \\
Barat II & 103 & 12 \\
Cibuk Lor I & 82 & 9 \\
Cibuk Lor II & 46 & 5 \\
Cibuk Kidul & 80 & 9 \\
Mandungan I & 49 & 6 \\
Mandungan II & 18 & 2 \\
Nengtak & 7 & 90 \\
Jumlah & 806 & \\
\hline & & \\
\hline
\end{tabular}

Sumber : Data Monografi Desa, 2019

Analisis kelayakan finansial usahatani pada penelitian ini ditekankan pada kegiatan usahatani padi. Data yang telah dikumpulkan kemudian diolah dan dianalisis. Analisis finansial usahatani padi meliputi: analisis biaya, penerimaan, pendapatan atau keuntungan hasil usahatani. Biaya usahatani yang dianalisis terdiri dari biaya tetap dan biaya variabel atau tidak tetap. Biaya variabel meliputi: biaya upah tenaga kerja mengolah lahan, merawat tanaman dan memanen serta penanganan pascapanen, pembelian benih, pembelian obat-obatan, pengangkutan hasil, sewa bajak, pembelian pupuk dan lainya, sedangkan biaya tetap melipui biaya untuk sewa lahan, sewa gudang, biaya perawatan alat dan lainnya. Menurut Soekartawi (2011); Suratiyah (2015) untuk menganalisis finansial usahatani dapat dihitung dari biaya total, penerimaan atau pendapatan dan nilai kelayakan. Adapun untuk menghitung total biaya usahatani digunakan persamaan sebagai berikut:

$\mathrm{TC}=\mathrm{TCV}+\mathrm{TCT}$

dimana:

$\mathrm{TC}=$ Biaya total usahatani (Rp)

$\mathrm{TCV}=$ Biaya variabel $(\mathrm{Rp})$

TCT $=$ Biaya tetap $(\mathrm{Rp})$

Besarnya penerimaan hasil usahatani dihitung dengan menggunakan persamaan sebagai berikut:
$\mathrm{TR}=\mathrm{Y} \cdot \mathrm{Py}$

di mana:

$\mathrm{TR}=$ Penerimaan Usahatani $(\mathrm{Rp})$

$\mathrm{Y}=$ Output yang diperoleh selama periode produksinya (ton)

Py = Harga dari hasil produksi (Rp/ton)

Sementara itu, untuk menghitung penerimaan petani dari hasil usahatani menggunakan persamaan sebagai berikut:

$\mathrm{TR}=\mathrm{Q} . \mathrm{Y}$

Dimana:

$\mathrm{Q}=$ hasil produksi (ton)

$\mathrm{Y}=$ harga komoditi

sedangkan besarnya keuntunga atau pendapatan bersih yang diterima petani digunakan persamaan sebagai berikut

$\pi=\mathrm{TR}-\mathrm{TC}$

dDi mana :

$\pi=$ Pendapatan bersih atau keuntungan (Rp)

$\mathrm{TR}=$ Penerimaan usahatani $(\mathrm{Rp})$

$\mathrm{TC}=$ Biaya total usahatani $(\mathrm{Rp})$

Untuk menghitung nilai kelayakan usahatani digunakan perhitungan dengan persamaan sebagai berikut:

$R /$ Cratio $=\mathrm{TR} / \mathrm{TC}$

dimana :

$\mathrm{R} / \mathrm{C}=$ Return Cost Ratio

$\mathrm{TR}=$ Penerimaan usahatani $(\mathrm{Rp})$

$\mathrm{TC}=$ Total biaya usahatani $(\mathrm{Rp})$

Kriteria :

$\mathrm{R} / \mathrm{C}>1$, usahatani layak diusahakan

$\mathrm{R} / \mathrm{C}<1$, usahatani tidak layak diusahakan

$\mathrm{R} / \mathrm{C}=1$, usahatani dikatakan impas

Persamaan lainya yang dapat digunakan untuk mengihitung kelayakan usahatani adalah $B / C$ ratio yaitu:

$B / C$ ratio $=\mathrm{B} / \mathrm{TC}$

dimana :

$\mathrm{B} / \mathrm{C}=$ Benefit/Cost Ratio

$\mathrm{B}=$ Pendapatan atau keuntungan bersih $(\mathrm{Rp})$

$\mathrm{TC}=$ Total biaya (Rp)

Kriteria :

$\mathrm{B} / \mathrm{C}>1$, usahatani layak diusahakan

$\mathrm{B} / \mathrm{C}<1$, usahatani tidak layak diusahakan

$\mathrm{B} / \mathrm{C}=1$, usahatani dikatakan impas

\section{HASIL PENELITIAN DAN PEMBAHASAN}

Deskripsi Lokasi Penelitian

Desa Margoluwih merupakan salah satu Desa yang berjarak $4 \mathrm{~km}$ dari Ibukota Kecamatan Sayegan atau sekitar $10 \mathrm{~km}$ dari Ibukota Kabupaten Sleman. Secara administrasi 
Desa Margoluwih merupakan gabungan dari 3 (tiga) kelurahan lama, yaitu: kelurahan Klangkapan, Barak dan Kelurahan Cibuk. Kelurahan Klangkapan meliputi lima 5 (lima) padusunan yaitu Dusun Klinyo, Dusun Togaten, Dusun Klangkapan, Dusun Klaci Lor dan Dusun Klaci Kidul. Kelurahan Barak meliputi 2 (dua) padusunan yaitu Dsun Barak Gede dan Dusun Barak Cilik, sedangkan Kelurahan Cibuk meliputi 4 (empat) padusunan yaitu Dusun Cibuk Lor, Dusun Cibuk Kidul, Dusun Mandungan dan Dusun Ngentak. Peta penggunaan lahan Desa Margolowih dapat dilihat pada Gambar 1.

Luas wilayah Desa Margoluwih sekitar 500 hektar yang terdiri dari lahan sawah seluas 248 hektar, lahan pertanian bukan sawah seluas 83,27 hektar dan lahan bukan pertanian seluas 168,73 hektar (Gambar 1). Jumlah penduduknya pada tahun 2019 tercatat sebanyak 9.659 jiwa yang terdiri dari penduduk laki-laki sebanyak 4.871 jiwa dan penduduk perempuan sebanyak 4.788 jiwa, dengan jumlah KK sebanyak 3.921 KK (BPS, 2019; Monografi Desa, 2019)

\section{Kondisi Sosial-Ekonomi dan Demografi Petani}

Kondisi sosial-ekonomi dan demografi petani yang dianalisis diantaranya adalah aspek pendidikan, umur, jumlah anggota rumahtangga, jumlah angota rumahtangga tani yang bekerja di pertanian dan penguasaan lahan pertanian. Menurut Nainggolan dan Johndikson (2016); Sudrajat (2018) bahwa aspek sosial-ekonomi dan demografi memiliki peranan penting dalam menentukan keputusan petani untuk memilih jenis komoditi yang akan diusahakan

Gambar 1. Peta Penggunaan Lahan di Desa Margoluwih

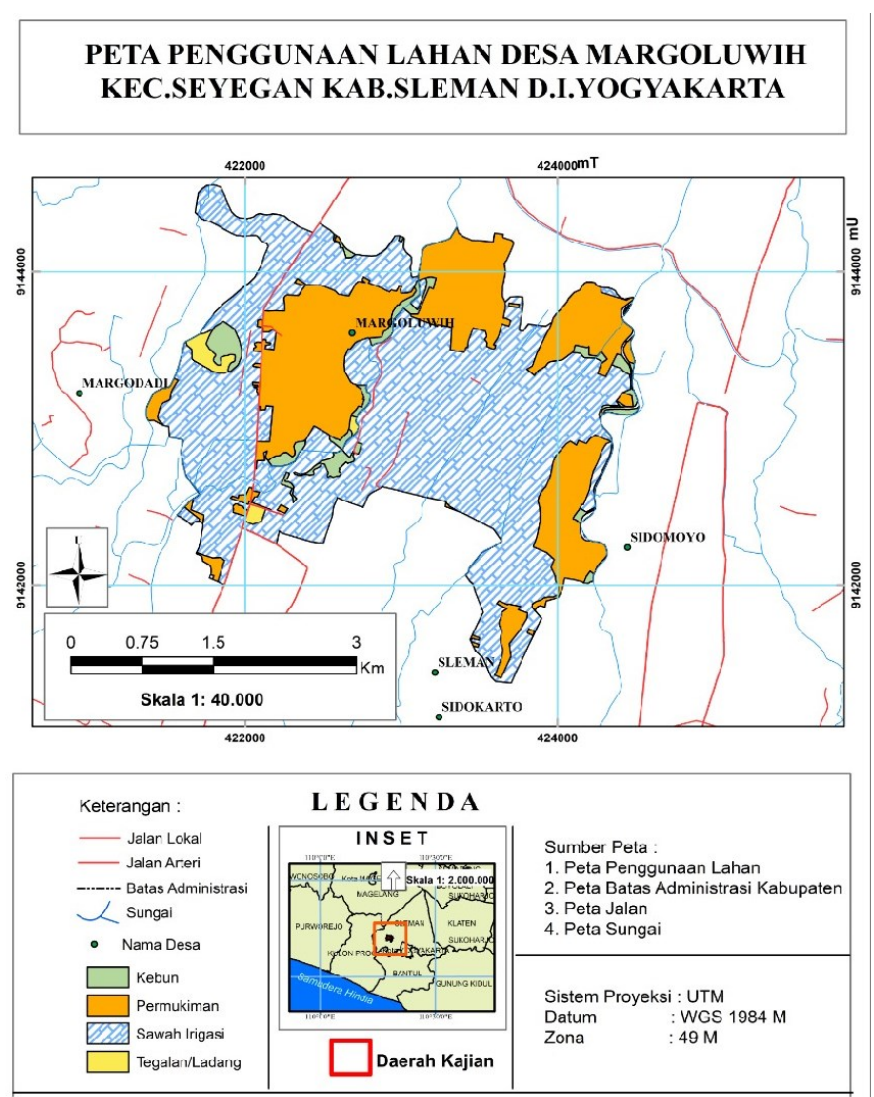

Tabel 2. Kondisi Sosial-Ekonomi dan Demografi Petani di Desa Margoluwih

\begin{tabular}{|c|c|c|}
\hline Karakteristik Petani & Frekuensi & $\begin{array}{c}\text { Persentase } \\
(\%)\end{array}$ \\
\hline \multicolumn{3}{|l|}{ A.Pendidikan Petani } \\
\hline 1.Tidak Tamat SD & 7 & 7,7 \\
\hline Tamat SD & 33 & 36.7 \\
\hline Tamat SLTP & 15 & 16,7 \\
\hline Tamat SLTA & 35 & 38.9 \\
\hline $\begin{array}{l}\text { Jumlah } \\
\text { B.Umur Petani }\end{array}$ & 90 & 100,0 \\
\hline Umur Produktif 64 tahun & 52 & 57,8 \\
\hline Umur Non Produktif $\geq 65$ tahun & 38 & 42,2 \\
\hline Jumlah & 90 & 100,0 \\
\hline \multicolumn{3}{|l|}{$\begin{array}{l}\text { C. Jumlah Anggota Rumahtang- } \\
\text { ga Tani }\end{array}$} \\
\hline$<3$ jiwa & 38 & 42,2 \\
\hline 3-5 jiwa & 49 & 54,5 \\
\hline$>5$ jiwa & 3 & 3,3 \\
\hline Jumlah & 90 & 100,0 \\
\hline \multicolumn{3}{|l|}{$\begin{array}{l}\text { D. Anggota Rumahtangga Tani } \\
\text { yang Bekerja di Pertanian }\end{array}$} \\
\hline$<2$ orang & 74 & 82,2 \\
\hline$\geq 2$ orang & 16 & 17,8 \\
\hline Jumlah & 90 & 100,0 \\
\hline \multicolumn{3}{|l|}{ E.Penguasaan Lahan Sawah } \\
\hline 1. $<0,25$ ha & 49 & 54,5 \\
\hline $0,25-0,5$ ha & 28 & 31,1 \\
\hline$>0,50$ ha & 13 & 14,4 \\
\hline Jumlah & 90 & 100,0 \\
\hline
\end{tabular}

Sumber: Data Primer, 2019

petani pada lahan pertaniannya. Dalam hal ini, petani dengan kondisi sosial ekonomi yang lebih baik dan masih tergolong produktif dari sisi umurnya akan lebih rasional dalam menentukan komoditi yang akan diusahakan. Hasil penelitian terkait dengan kondisi sosial-ekonomi dan demografi petani di lokasi penelitian disajikan pada Tabel 2.

Hasil penelitian pada Tabel 2 tampak sebagian besar petani di Desa Margoluwih masih tergolong produktif dan dilihat pendidikannya sebagian besar masih rendah yaitu tamat SD, sedangkan dilihat dari jumlah anggota rumahtangganya sebagian besar berjumlah diantara 3-5 jiwa. Sementara itu, dilihat dari jumlah anggota rumahtangga yang bekerja di pertanian sebagian besar hanya $<2$ orang. Menurut Nainggolan dan Johndikson (2016); Hoar dan Yoseffina (2017) kondisi sosial-ekonomi dan demografi 
tersebut akan sangat berpengaruh terhadap aktivitas produksi pertanian yang dilakukan petani dalam meningkatkan pendapatan petani. Oleh karena itu, dalam pembangunan pertanian yang menekankan keterkaitan aspek sosial-ekonomi dan demografi petani dengan peningkatan produksi pertanian harus menjadi perhatian utama.

\section{Finansial Usahatani Padi}

Analisis kelayakan finansial usahatani merupakan sistem keuangan usahatani yang dapat meliputi biaya, penerimaan, pendapatan dan keuntungan yang diterima petani dari kegiatan usahatani. Besarnya nilai finansial yang diterima petani sangat dipengaruhi oleh besarnya total biaya yang dikeluarkan petani per satuan luas lahan. Total biaya yang dikeluarkan petani dalam proses kegiatan usahatani bisa berasal dari biaya tidak tetap dan biaya tetap. Pada umumnya biaya yang paling banyak dikeluarkan petani adalah biaya tidak tetap yaitu; untuk pembelian pembelian obat-obatan, pupuk, bibit, upah tenaga kerja dan biaya membajak lahan, sedangkan untuk biaya tidak tetapnya sering hanya berupa biaya sewa lahan atau perawatan peralatan pertanian (Maulidah dan Pratiwi, 2010; Suratiyah, 2015; Mamilianti, 2015). Hasil penelitian terkait dengan biaya tetap dan biaya tidak tetap yang digunakan petani dalam kegiatan usahatani padi secara lebih rinci disajikan dalam Tabel 3.

Hasil penelitian sebagaimana tercantum pada Tabel 3 tampak rata-rata biaya usahatani padi dengan rata-rata luas penguasaan lahan sawah seluas 0,35 ha membutuhan biaya sebesar Rp 3.377.534,- per musim tanam. Pada biaya tidak tetap yang paling besar pengeluarannya adalah untuk biaya

Tabel 3.Rata-Rata Biaya Usahatani Padi di Desa Margoluwih

\begin{tabular}{lc}
\hline Jenis Biaya Usahatani & Rata-rata (Rp/MT) \\
\hline A. Biaya Tetap & 195.777 \\
Biaya perawatan alat & 202100 \\
Biaya sewa lahan & 230.744 \\
Rata-Rata Biaya Tetap & \\
A. Biaya Tidak Tetap & 316.596 \\
$\quad$ Biaya pembelian bibit & 369.979 \\
$\quad \begin{array}{l}\text { Biaya pupuk dan obat-obatan } \\
\text { Biaya sewa traktor dan upah } \\
\text { tenaga kerja pengolahan lahan }\end{array}$ & 384.222 \\
$\quad \begin{array}{l}\text { Baiaya upah tenaga kerja } \\
\text { perawatan/penyiangan }\end{array}$ & 202.100 \\
Biaya upah tenaga kerja pema- \\
$\quad$ nenan \\
$\begin{array}{l}\text { Biaya pengangkutan hasil } \\
\text { Total Rata-Rata Biaya Tidak Tetap }\end{array}$ \\
\begin{tabular}{l} 
Rata-Rata Total Biaya \\
\hline
\end{tabular}
\end{tabular}

Sumber: Data Primer, 2019 pembilan pupuk dan obat-obatan, sedangkan biaya paling rendah adalah biaya utuk pengangkutan hasil panen. Biaya yang paling tinggi untuk biaya tetap adalah biaya untuk sewa lahan, sedangkan untuk biaya perawatan alat pertanian relatif lebih rendah. Total biaya yang dikeluarkan untuk kegiatan usahatani pada akhirnya akan mempengaruhi besarnya penerimaan petani dari hasil kegiatan usahatani.

Biaya usahatani sering juga disebut sebagai biaya faktor produksi yang akan berpengaruh terhadap besarnya pendapatan yang akan diterima petani. Oleh karena itu, cukup wajar jika petani selalu berusaha meningkatkan kualitas maupun kuantitas produksi, agar biaya yang dikeluarkan dapat ditutupi oleh pendapatan yang diterima, sehingga petani mendapatkan keuntungan yang maksimum. Namun demikian, besarnya biaya produksi yang keluarkan petani tidak terlepas dari luas lahan yang diusahakan untuk kegiatan usahatani. Hal ini sejalan dengan yang dikemukan Mamondol dan Sabe (2016) bahwa luas lahan yang diusahakan petani memiliki hubungan positif dengan biaya yang dikeluarkan dan pendapatan yang diterima petani. Ini berarti semakin luas lahan pertanian yang diusahakan petani, akan semakin besar biaya produksi yang di keluarkan, namun pendapatan yang diterima juga akan semakin besar dan akan terjadi sebaliknya. Hasil penelitian terkait dengan hasil produksi padi yang diusahakan petani di lokasi penelitian dapat dilihat pada Tabel 4 .

Hasil penelitian menemukan produksi padi di lokasi penelitian rata-rata hanya sebesar 1,8 ton per musim tanam. Sementara itu, dilihat dari distribunya pada Tabel 4 tampak sebagain besar petani hanya mampu memproduksi padi sebesar $<2,5$ ton per musim tanam, sedangkan yang mampu memproduksi padi berkisar diantara 2,5-5 ton per musim tanam hanya sebanyak 20,0\% dan sisanya sebanyak 6,7\% mampu memproduksi padi $>5$ ton per musim tanam. Fenomena ini menunjukkan bawa produksi padi setiap musim tanam di lokasi penelitian tergolong rendah. Hal ini terjadi bukan karena rendahnya penggunaan faktor produksi, namun lebih banyak disebabkan karena luas lahan sawah yang diusahakan petani rata-rata hanya seluas 0,35 ha. Hasil ini sejalan dengan yang dikemukakan Prayoga (2010); Suratiyah (2015); Mamondol \& Sabe (2016); Simanullang \&

Tabel 4. Rata-Rata Produksi Usahatani Padi di Desa Margoluwih

\begin{tabular}{lcc}
\hline $\begin{array}{l}\text { Rata-Rata Hasil Produksi } \\
\text { Padi (Ton/Musim Tanam) }\end{array}$ & Frekuensi & Persentase (\%) \\
\hline$<2,5$ ton/musim & 66 & 73,3 \\
$2,5-5$ ton/musim & 18 & 20,0 \\
$>5$ ton/musim & 6 & 6,7 \\
Total & 90 & 100,0 \\
\hline
\end{tabular}

Sumber: Data Primer, 2019 
Saragih (2017) bahwa luas lahan merupakan faktor produksi yang akan menentukan besarnya produksi lahan pertanian dan pada akhinya menentukan besarnya penerimaan petani. Hasil penelitian terkait hubungan antara luas lahan menurut besarnya produksi padi di lokasi penelitian dapat dilihat pada Tabel 5 berikut.

Hasil penelitian pada Tabel 5 tampak ada perbedaan besarnya produksi padi yang dihasilkan petani menurut luas lahan sawah yang dikuasai. Jika dilihat dari distribusi tampak ada kecenderungan semakin sempit lahan sawah yang dikuasi petani semakin kecil produksi padi yang dihasilkan dan terjadi sebaliknya semakin luas lahan yang dikuasi semakin besar produksi padi yang dihasilkan. Menurut Novianto \& Setyowati (2009); Sari dkk. (2018) fenomen memberikan gambar bahwa faktor luas lahan mempengaruhi besarnya produksi padi yang dihasilkan petani setiap musim tanam.

Produksi padi yang dihasilkan petani di lokasi penelitian merupakan salah satu komoditi utama yang menjadi penerimaan petani dari hasil kegiatan usahataninya. Penerimaan hasil usahatani padi pada dasarnya tidak terlepas dari tinggi rendahnya harga jual komoditi padi. Ini berarti, penerimaan merupakan banyaknya produksi atau ouput

Tabel 5. Luas Sawah Menurut Besarnya Produksi Padi di Desa Margoluwih

\begin{tabular}{lcccc}
\hline & \multicolumn{3}{c}{ Produksi Pad (ton) } & \\
\cline { 2 - 4 } Luas Lahan (ha) & $<2,5$ Ton & $2,5-5$ Ton & $>5$ Ton & Total \\
& $(\%)$ & $(\%)$ & $(\%)$ & \\
\hline \multirow{2}{*}{$<0,25$ ha } & 47 & 1 & 1 & 49 \\
& $(52,2)$ & $(1,1)$ & $(1,1)$ & $(54,4)$ \\
$0,25-0,5$ ha & 19 & 9 & 0 & 28 \\
& $(21,1)$ & $(10,0)$ & $(0,0)$ & $(31,1)$ \\
$>0,5$ ha & 0 & 8 & 5 & 13 \\
& $(0,0)$ & $(8,9)$ & $(5,6)$ & $(14,4)$ \\
Total & 66 & 18 & 6 & 90 \\
& $(73,3)$ & $(20,0)$ & $(6,7)$ & $(100,0)$ \\
\hline
\end{tabular}

Sumber: Data Primer, 2019

Tabel 6. Penerimaan Petani Dari Usahatani Padi di Desa Margoluwih

\begin{tabular}{lcc}
\hline $\begin{array}{c}\text { Penerimaan Hasil Usahatani } \\
\text { Padi (Rp/Musim Tanam) }\end{array}$ & Frekuensi & Persentase (\%) \\
\hline$<$ Rp 10.000.000,- & 61 & 67,8 \\
Rp 10.000.000-15.000.000,- & 15 & 16,7 \\
$>$ Rp15.000.000 & 14 & 15,6 \\
Total & 90 & 100,0 \\
\hline
\end{tabular}

Sumber: Data Primer, 2019 suatu komoditi hasil usahatani dikalikan dengan harga jual komoditi tersebut. Dengan demikian, maka semakin tinggi harga jual komoditi padi semakin besar penerimaan yang diterima petani, dan terjadi sebaliknya semakin rendah harga jual komoditi padi akan semakin rendah pula penerimaan petani. Hasil penelitian terkait dengan penerimaan hasil usahatani padi di lokasi penelitian dapat dilihat pada Tabel 6.

Hasil penelitian pada Tabel 6 menemukan rata-rata penerimaan petani dari hasil usahatani padi hanya sebesar Rp 8.082.273,- per musim tanam. Rendahnya rata-rata penerimaan petani tersebut terjadi karena sebagian besar penerimaan petani hanya $\mathrm{Rp}<10.000 .000$,- per musim tanam, sedangkan yang penerimaanya berkisar diantara $\mathrm{Rp}$ 10.000.000-15.000.000,- sebanyak 16,7\% dan yang penerimaannya Rp >15.000.000,- hanya sebanyak 15,6\%. Variasi besarnya penerimaan petani dari hasil usahatani padi memberikan gambaran adanya variasi besarnya hasil produksi. Hasil penelitian terkait antara besarnya hasil produksi dengan penerimaan yang diterima petani dapat dilihat pada Tabel 7.

Hasil penelitian pada Tabel 7 tampak ada perbedaan besarnya penerimaan petani menurut besarnya produksi padi. Jika dilihat dari distribusinya tampak ada kecenderungan semakin besar produksi padi yang dihasilkan petani semakin besar penerimaan petani, dan terjadi sebalinya semakin kecil produksi padi yang dihasilkan petani semakin kecil pula penerimaan petani. Fenomen ini memberikan gambar adanya kecenderungan hubungan positif antara besarnya produksi padi yang dihasilkan petani dengan besarnya penerimaan. Penerimaan petani dari hasil usahatani tersebut pada akhirnya akan mempengaruhi besarnya pendapatan yang diterima petani.

Pendapatan usahatani merupakan besarnya penerimaan usahatani yang diterima oleh petani padi dikurangi dengan

Tabel 7. Hasil Produksi Padi Menurut Penerimaan Hasil Usahatani Padi di Desa Margoluwih

\begin{tabular}{|c|c|c|c|c|}
\hline \multirow{3}{*}{$\begin{array}{l}\text { Hasil Produksi } \\
\text { (Ton/musim } \\
\text { tanam) }\end{array}$} & \multicolumn{3}{|c|}{ Penerimaan Hasil Usahatani (Rp) } & \multirow{3}{*}{ Jumlah } \\
\hline & $\mathrm{Rp} 10 \mathrm{Jt}$ & Rp $10-15 \mathrm{Jt}$ & $\mathrm{Rp}>15 \mathrm{Jt}$ & \\
\hline & (\%) & $(\%)$ & (\%) & \\
\hline \multirow{2}{*}{$<2,5$ ton } & 61 & 5 & 0 & 66 \\
\hline & $(67,8)$ & $(5,6)$ & $(0,0)$ & $(73,3)$ \\
\hline \multirow{2}{*}{$2,5-5$ ton } & 0 & 10 & 8 & 18 \\
\hline & $(0,0)$ & $(11,1)$ & $(8,9)$ & $(20,0)$ \\
\hline \multirow{2}{*}{$>5$ ton } & 0 & 0 & 6 & 6 \\
\hline & $(0,0)$ & $(0,0)$ & $(6,7)$ & $(6,7)$ \\
\hline \multirow{2}{*}{ Jumlah } & 61 & 15 & 14 & 90 \\
\hline & $(67,8)$ & $(16,7)$ & $(15,6)$ & $(100,0)$ \\
\hline
\end{tabular}

Sumber: Data Primer, 2019 
total biaya yang dikeluarkan untuk biaya produksi usahatani. Dengan demikian, maka besar kecilnya pendapatan yang diterima petani akan sangat dipengaruhi oleh besar kecil pengeluaran untuk biaya tetap maupun biaya tidak tetap. Ini berarti semakin besar total biaya yang dikeluarkan petani untuk upah tenaga kerja dalam pengolahan lahan, perawatan, pemanenan maupun pascapanen, sewa traktor, pembelian bibit, obat-obatan, perawatan alat, sewa lahan, pengakutan dan pupuk, sewa lahan dan perawatan alat pertanian, maka akan semakin kecil pendapatan bersih yang diterima petani dan akan terjadi sebaliknya (Tohir, 1991; Syarif, (2011); Simanullang \& Saragih (2017); Palabo dkk, 2019). Selain itu faktor yang mempengaruhi pendapatan adalah luas lahan yang diusahakan petani (Mawardati, 2013; Munandar, 2016).Hasil penelitian terkait dengan pendapatan yang diterima petani dari hasil usahatani di lokasi penelitian secara lebih rinci dapat dilihat pada Tabel 8.

Hasil penelitian pada Tabel 8 menemukan rata-rata pendapatan yang diterima petani dari hasil usahatani padi hanya sebesar Rp 4.704.739,- per musim tanam (MT). Sementara itu, dilihat dari distribusinya tampak ada variasi besarnya pendapatan usahatani yang diterima petani. Hal ini terlihat dari jumlah petani yang menerima pendapatan $\mathrm{Rp}$ $<5.000 .000$,- per musim tanam sangat dominan yaitu sebanyak 58,9\% dan yang menerima pendapatan antara $\mathrm{Rp}$ 5.000.000-10.000.000,- per musim tanam sebanyak 32,2\%, sedangkan yang menerima pendapatan $\mathrm{Rp}>10.000 .000$ per musim tanam hanya sebanyak $8,9 \%$. Walaupun besarnya pendapatan yang diterima petani bervariasi, namun masih dapat dikatakan pendapatan usahatani tersebut masih menguntungkan. Besar kecilnya pendapatan yang diterima petani tidak terlepas dari besarnya penerimaan dan biaya yang dikeluarkan. Ini berarti semakin besar penerimaan dari hasil usahatani dan semakin kecil biaya maka akan semakin besar pendapatan yang diterima petani dan terjadi sebaliknya (Nainggolan dan Johndikson, 2016; Mamondol dan Sabe, 2016; Munizar, dkk. 2019).

Kelayakan Finansial Usahatani Padi

Kelayakan finansial usahatani padi merupakan suatu analisis yang bertujuan untuk melihat keadaan finansial

Tabel 8. Pendapatan Hasil Usahatani Padi Yang Diterima Petani di Desa Margoluwih

\begin{tabular}{lll}
\hline $\begin{array}{l}\text { Pendapatan Usahatani } \\
\text { Padi (Rp/Musim Tanam }\end{array}$ & Frekuensi & Presentase (\%) \\
\hline Rp <5.000.000,- & 53 & 58,9 \\
Rp 5.000.000-10.000.000,- & 29 & 32,2 \\
Rp >10.000.000,- & 8 & 8,9 \\
Jumah & 90 & 100,0 \\
\hline
\end{tabular}

Sumber: Data Primer, 2019 usahatani padi yang dilakukan petani pada suatu lahan, pada periode waktu tertentu dengan mengunakan paket input tertentu. Menurut Soekartawi (2011); Suratiyah, (2015); Palobo dkk. (2019) kelayakan fnansial usahatani dapat dihitung dengan menggunakan $R / C$ ratio atau $B / C$ ratio. Analisis $R / C$ ratio atau Revenue Cost ratio merupakan perbandingan atau nisbah antara penerima dan biaya, sedangkan analisis $\mathrm{B} / \mathrm{C}$ Ratio atau Benefit Cost ratio merupakan perbandingan antara manfaat dan biaya. Keduanya memiliki fungsi yang sama yaitu untuk mengetahui nilai kelayakan, dengan asumsi semakin besar revenue atau benefit yang diterima petani akan semakin besar nilai kelayakan. Hasil perhitungan kelayakan usahatani padi di lokasi penelitian dapat dilihat pada Tabel 9.

Hasil perhitungan $R / C$ ratio pada Tabel 9 tampak nilai $R /$ $C$ ratio sebesar 3,24. Ini berarti setiap $\mathrm{Rp} 1$,- yang dikeluarkan oleh petani akan diperoleh keuntungan sebesar Rp 3,24,- per musim tanam. Sementara itu, dari perhitungan $B / C$ ratio diperoleh nilai $B / C$ ratio sebesar 2,22. Ini berarti setiap $\mathrm{Rp} 1$,yang dikeluarkan oleh petani akan diperoleh keuntungan sebesar Rp 2,22,- per musim tanam. Berdasarkan kedua hasil perhitungan tersebut maka rata-rata kegiatan usahatani di lokasi penelitian masih layak diusahakan karena nilai kelayakan usahataninya, baik menggunakan $R / C$ ratio maupun $B / C$ ratio sama-sama nilainya $>1$. Variasi nilai kelayakan usahatani dengan metode $R / C$ ratio dan $B / C$ ratio di lokasi penelitian secara lebih rinci dapat dilihat pada Tabel 10 .

Hasil perhitungan kelayakan pada Tabel 10 tampak nilai $R / C$ ratio nilainya tidak ada yang $<1$, sedangkan yang nilai $R / C$ ratio anatar $1-2$ ada sebanyak $16,7 \%$ dan yang $R / C$ ratio $>2$ ada sebanyak 83,3\%. Ini berarti ada sebanyak 16,7\% setiap Rp 1,- yang dikeluarkan petani akan mendapatkan keuntungan sebesar Rp 1-2,- per musim tanam dan ada sebanyak 83,3\% akan mendapatkan keuntungan sebesar Rp $>2$,- per musim tanam. Dengan demikian berdasarkan nilai $R / C$ ratio maka kegiatan usahatani yang dilakukan setiap petani di lokasi penelitian masih layak karena nilai kelayakannya $>1$.

Tabel 9. Nilai Kelayakan Finansial Usahatani Padi di Desa Margoluwih

Nilai Kelayakan Usahatani

Rata-rata penerimaan

Rp 8.082.273,

Rata-Rata Pendapatan

Rp 4.704.738,-

Rata-Rata Biaya tetap

Rp 230.744.-

Rata-Rata Total Biaya

Rp 3.799.314,-

Revenue/Cost Ratio (R/C Ratio)

Benefit/Cost Ratio (B/C Ratio)

Sumber: Data Primer, 2019

http://jurnal.ugm.ac.id/mgi 59 
Tabel 10. Besar Variasi Nilai Kalayakan Usahatani Padi di Desa Margoluwih

\begin{tabular}{lcrcc}
\hline & \multicolumn{3}{c}{ R/C Ratio } & \multicolumn{3}{c}{ B/C Ratio } \\
\cline { 2 - 6 } Nilai & F & $\%$ & F & $\%$ \\
Kelayakan & & & & \\
\hline Nilai Kelayakan <1 & 0 & 0,0 & 15 & 16,7 \\
Nilai Kelayakan 1-2 & 15 & 16,7 & 24 & 26,7 \\
Nilai Kelayakan $>2$ & 75 & 83,3 & 51 & 56,6 \\
\hline Jumlah & 90 & 100,0 & 90 & 100,0 \\
\hline
\end{tabular}

Sumber: Data Primer, 2019

Berbeda dengan hasil perhitungan $B / C$ ratio pada Tabel 10 tampak ada sebanyak $16,7 \%$ petani dengan nilai $B / C$ ratio $<1$, sedangkan yang nilai $B / C$ ratio antara 1-2 ada sebanyak $26,7 \%$ dan nilai $B / C$ ratio $>2$ ada sebanyak $56,6 \%$. Ini berarti dengan perhitungan $B / C$ ratio ada sebanyak $83,3 \%$ kegiatan usahataninya layak karena nilai $B / C$ ratio $>1$. Dengan demikian maka dari sebanyak $83,3 \%$ setiap Rp 1,- yang dikeluarkan petani, sebanyak 26,7\% akan mendapatkan keuntungan sebesar Rp 1-2,- per musim tanam dan sebanyak $56,6 \%$ akan mendapatkan keuntungan $\mathrm{Rp}>2$ per musim tanam.

Sementara itu, dari sebanyak $16,7 \%$ petani yang nilai kelayakannya $<1$ memberikan makna bahwa kegiatan usahataninya tidak layak. Fenomena tersebut disebabkan karena biaya yang dikeluarkan petani cukup besar, sedangkan lahan sawah yang dikuasai relatif sempit sehingga keuntungan yang diperoleh menjadi kecil. Hal ini sejalan dengan temuan hasil penelitian Edyson dkk., (2015) yang menemukan bahwa rendahnya nilai kelayakan disebabkan karena tingginya biaya produksi dan belum maksimal produksi usahataninya.

Walaupun dari nilai $R / C$ ratio dan $B / C$ ratio menunjukkan adanya perbedaan nilainya, namun dari hasil perhitungan rata-ratanya seperti yang tampak pada Tabel 9 menunjukkan bahwa kegiatan usahatani di lokasi penelitian masih layak karena nilai kelayakannya $>1$. Hasil penelitian keterkaitan antara biaya dengan nilai kelayakan usahatani padi di lokasi penelitian dapat dilihat pada Tabel 11.

Hasil analisis seperti pada Tabel 11 menunjukkan adanya keterkaitan antara biaya yang dikeluarkan petani dengan besarnya nilai $R / C$ ratio. Hal ini tampak dari jumlah petani mengeluarkan biaya $\mathrm{Rp}<1,5$ juta per musim tanam diikuti dengan nilai kelayakan $>2$ jumlahnya mencapai $61,1 \%$, sedangkan jumlah petani yang diikuti dengan nilai kelayakan berkisar 1-2 hanya 8,9\%. Keterkaitan antara biaya usahatani dengan nilai kelayakan dapat juga dilihat dari nilai $B / C$ ratio. Hasil analisis keterkaitan biaya usahatani padi dengan nilai $B / C$ ratio dapat dilihat pada Tabel 12 .

Hasil analisis B/C Ratio pada Tabel 12 menunjukkan
Tabel 11. Biaya Usahatani Padi Menurut Nilai R/C Ratio di Desa Margoluwih

\begin{tabular}{|c|c|c|c|}
\hline \multirow[b]{2}{*}{$\begin{array}{c}\text { Besarnya Biaya } \\
\text { Usathaani }\end{array}$} & \multicolumn{2}{|c|}{ Nlai Kelayakan $R / C$ Ratio } & \multirow[b]{2}{*}{ Jumlah } \\
\hline & $\begin{array}{c}\text { Nilai } \\
\text { Kelayakan } \\
\text { antara 1-2 }\end{array}$ & $\begin{array}{c}\text { Nilai } \\
\text { Kelayakan } \\
>2\end{array}$ & \\
\hline \multirow{2}{*}{$\mathrm{Rp}<1,5 \mathrm{Jt}$} & 8 & 47 & 55 \\
\hline & $8,9 \%$ & $52,2 \%$ & $61,1 \%$ \\
\hline \multirow{2}{*}{ Rp $1,5-2,5 \mathrm{Jt}$} & 3 & 16 & 19 \\
\hline & $3,3 \%$ & $17,8 \%$ & $21,1 \%$ \\
\hline \multirow{2}{*}{$\mathrm{Rp}>2,5 \mathrm{jt}$} & 4 & 12 & 16 \\
\hline & $4,4 \%$ & $13,3 \%$ & $17,8 \%$ \\
\hline \multirow{2}{*}{ Jumlah } & 15 & 75 & 90 \\
\hline & $16,7 \%$ & $83,3 \%$ & $100,0 \%$ \\
\hline
\end{tabular}

Sumber: Data Primer, 2019

Tabel 12. Biaya Usahatani Padi Menurut Nilai B/C Ratio di Desa Margoluwih

\begin{tabular}{ccccc}
\hline Besarnya & \multicolumn{3}{c}{ Nilai Kelaykan B/C Rasio } & \\
\cline { 2 - 4 } $\begin{array}{c}\text { Biaya } \\
\text { Usathaani } \\
\text { (Juta) }\end{array}$ & $\begin{array}{c}\text { Nilai } \\
\text { Kelayakan } \\
<1\end{array}$ & $\begin{array}{c}\text { Nilai } \\
\text { Kelayakan }\end{array}$ & $\begin{array}{c}\text { Nilai } \\
\text { Kelayakan }\end{array}$ & Total \\
\hline Rp $<1,5$ & 7 & $1-2$ & $>2$ & \\
\hline Rp 1,5-2,5 & $7,8 \%$ & $18,9 \%$ & $34,4 \%$ & $61,1 \%$ \\
& 3 & 2 & 14 & 19 \\
Rp $>2,5$ & $3,3 \%$ & $2,2 \%$ & $15,6 \%$ & $21,1 \%$ \\
& 5 & 5 & 6 & 16 \\
Jumlah & $5,6 \%$ & $5,6 \%$ & $6,7 \%$ & $17,8 \%$ \\
& 15 & 24 & 51 & 90 \\
\hline
\end{tabular}

Sumber: Data Primer, 2019

adanya kecenderungan yang sama dengan hasil analisis $R / C$ ratio, yaitu pada petani yang mengeluarkan biaya usahatani $\mathrm{Rp}<1,5$ juta per musim tanam dengan nilai kelayakan yang tinggi $>2$ jumlahnya mencapai $34,4 \%$, sedangkan petani dengan nilai kelayakan <1 hanya sebanyak $7,8 \%$. Berdasarkan hasil analisis tersebut maka dapat dikatakan bahwa kelayakan usahatani sangat terkait dengan besar kecilnya biaya yang dikeluarkan petani dalam kegiatan usahatani.

Pengaruh Kelayakan Usahatani Padi Terhadap Pendapatan

Analisis kelayakan finansial merupakan salah satu aspek penting yang perlu diketahui dalam kegiatan usahatani. Hal ini terjadi karena dengan menganalisis kelayakan finansial usahatani diharapakan mampu memperkirakan besarnya tingkat kelayakan suatu usahatani yang dilakukan petani. Kegiatan usahatani yang dinilai layak secara finansial akan 
Tabel 13. Nilai R/C Ratio Menurut Pendapatan Usahatani Padi di Desa Margoluwih

\begin{tabular}{lcccc}
\hline \multirow{2}{*}{$\begin{array}{c}\text { Nilaia } \\
\text { Kelayakan (R/ } \\
\text { C Ratio) }\end{array}$} & \multicolumn{3}{c}{ Pendapatan Usahatani } & \\
\cline { 2 - 4 } Rp> 5Jt & Rp 5- 10 Jt & Rp >10 Jt & \\
\hline 1.Kelayakan $\geq 1$ & 13 & 2 & 0 & 15 \\
-2 & $14,4 \%$ & $2,2 \%$ & $0,0 \%$ & $16,7 \%$ \\
2.Kelayakan $>2$ & 40 & 27 & 8 & 75 \\
& $44,4 \%$ & $30,0 \%$ & $8,9 \%$ & $83,3 \%$ \\
Jumlah & 53 & 29 & 8 & 90 \\
& $58,9 \%$ & $32,2 \%$ & $8.9 \%$ & $100,0 \%$ \\
\hline
\end{tabular}

Sumber: Data Primer, 2019

Tabel 14. Nilai B/C Ratio Menurut Pendapatan Usahatani di Desa Margoluwih

\begin{tabular}{ccccc}
\hline \multirow{2}{*}{ Nilai } & \multicolumn{3}{c}{ Pendapat Bersih } & \multirow{2}{*}{ Total } \\
\cline { 2 - 4 } Kelayakan & Rp <5 Jt & Rp 5 -10 Jt & Rp > 10Jt & \\
\hline \multirow{2}{*}{ Nilai $<1$} & 11 & 4 & 0 & 15 \\
& $12,2 \%$ & $4,4 \%$ & $0,0 \%$ & $16,7 \%$ \\
Nilai 1-2 & 19 & 4 & 1 & 24 \\
& $21,1 \%$ & $4,4 \%$ & $1,1 \%$ & $26,7 \%$ \\
Nilai $>2$ & 23 & 21 & 7 & 51 \\
& $25,6 \%$ & $23,3 \%$ & $7,8 \%$ & $56,7 \%$ \\
Jumlah & 53 & 29 & 8 & 90 \\
& $58,9 \%$ & $32,2 \%$ & $8,9 \%$ & $100,0 \%$ \\
\hline
\end{tabular}

Sumber: Data Primer, 2019

memiliki pengaruh besar terhadap besarnya pendapatan yang akan diterima petani dan terjadi sebaliknya (Rustam, 2014; Munizar dan Dance, 2019). Hasil penelitian keterkaitan antara nilai kelayakan dengan pendapatan yang diterima petani di lokasi penelitian dapat dilihat pada Tabel 13 .

Hasil penelitian seperti yang tampak pada Tabel 13 menunjukkan ada kecenderungan nilai kelayakan $R / C$ ratio berpengaruh terhadap besarnya pendapatan yang diterima petani. Hasil ini diperkuat dari hasil uji regresi linier yang menunjukkan nilai $R$ Square sebasar 0,301 dengan nilai sig.0,000. Ini berarti secara signifikan besarnya pendapatan usahatani yang diterima petani dipengaruhi oleh nilai kelayakan sebesar $30,1 \%$ dan sisanya sebanyak $69,9 \%$ dipengaruhi oleh faktor lain di luar kajian ini. Kecenderungan nilai kelayakan berpengaruh terhadap pendapatan, tercermin juga dari hunbungan antara nilai $B /$ $C$ Ratio dengan pendapatan. Secara lebih jelas kecenderungan bahwa nilai $B / C$ Ratio berpengaruh terhadap pendapatan yang diterima petani di lokasi penelitian dapat dilihat pada Tabel 14

Hasil analisis pada Tabel 14 tampak ada kecenderungan bahwa nilai $B / C$ Ratio berpengaruh terhadap pendapatan.
Kecenderungan tersebut diperkuat dengan analisis regresi yang menunjukkan nilai $R$ square sebesar 0,59 dengan nilai sig. 0,012. Ini berarti pendapatan yang diterima petani dipengaruhi oleh nilai kelayakan $R / C$ ratio sebesar 59,0\% dan sisanya sebanyak $51,0 \%$ dipengaruhi faktor lain. Berdasarkan hasil analisis tersebut dapat dikatakan bahwa faktor nilai kelayakan ( $R / C$ Ratio maupun $B / C$ ratio) berpengaruh positif terhadap pendapatan yang diterima petani. Ini berarti makin besar nilai $R / C$ ratio atau $B / C$ ratio semakin besar pendapatan yang akan diterima petani (Soekartawi, 2011).

\section{KESIMPULAN}

Hasil penelitian menemukan bahwa kondisi sosialekonomi dan demografi petani yang dikaji dari aspek umur, pendidikan, jumlah anggota rumahtangga, jumlah angota rumahtangga yang bekerja di pertanian dan penguasaan lahan pertanian cukup bervariasi. Hasil analisis finansial usahatani menunjukkan adanya variasi biaya usahatani menurut luas lahan dan variasi penerimaan atau pendapatan menurut perbedaan hasil produksi dan biaya. Berdasarkan analisis kelayakan usahatani padi dengan $R / C$ ratio maupun dengan $B / C$ ratio menunjukkan bahwa kegiatan usahatani padi masih layak dan secara signifikan nilai kelayakan tersebut berpengaruh positif terhadap pendapatan yang diterima petani.

\section{UCAPAN TERIMA KASIH}

Pada kesempatan ini penulis mengucapkan banyak terima kasih kepada Fakultas Geografi yang telah memberikan Dana Hibah Mandiri UGM Tahun 2019. Penulis juga, mengucapkan banyak mengucapkan terima kasih kepada kepada Asisten Lapangan yang telah membantu dalam pengumpulan data lapangan.

\section{DAFTAR PUSTAKA}

Badan Pusat Statistik. (2019). Kecamatan Sayegan Dalam Angka. Sleman. BPS Kabupaten Sleman.

Barokah U., W. Rahayu dan M.T. Sundari. (2014). Analisis Biaya dan Pendapatan Usahatani Padi di Kabupaten Karanganyar. Jurnal Agric. Vol. (26)1: Hal. 12-19.

Edyson M. D. A., Natelda. R. T. dan J. M. Luhukay. (2015). Analisis Tingkat Kelayakan Usahatani Padi Sawah (Studi Kasus Di Desa Wanareja Kecamatan Waepo Kabupaten Buru). Jurnal Agrilan. Vol. 3(2): Hal. 179-190.

Gilarso S. J. (2003). Pengantar Ilmu Ekonomi Mikro. Yogyakarta. Kanisius.

Gittinger, J. P. dan Adler. A H. (1993). Analisis Ekonomi Proyek-Proyek Pertanian. Cetakan Ketiga. PT. Rineka Cipta. Jakarta.

Gustiana C. (2015). Strategi Pembangunan Pertanian Dan Perekonomian Pedesaan Melalui Kemitraan Usaha Berwawasan Agribisnis. Jurnal AGRISAMUDRA.Vol. (2)1: Hal. 780 . 
Hoar E. dan Yoseffina M.F. (2017). Pengaruh Faktor Sosial Ekonomi Petani terhadap Produksi Usahatani Jagung di Desa Badarai Kecamatan Wewiku Kabupaten Malaka. Jurnal Agrimor. Vol. 2(3): Hal. 36-38.

Kantor Desa Margolowih. (2019). Monografi Desa Margoluwih. Kantor Desa Morgoluwih. Pemerintahan Desa Margoluwih Kecamaran Sayegan.

Khai H.V. and M. Yabe. (2011). Technical Efficiency Analysis of Rice Production in Vietnam. Journal of ISSAAS. 17 (1) : 135146.

Mamilianti W. (2015). Analisis Ekonomi Usahatani Padi Organik Di Prigen Pasuruan. Jurnal Argromix. Vol (6)1: Hal. 20-37.

Mamondol M. dan F. Sabe. (2016). Pengaruh Luas Lahan Terhadap Penerimaan, Biaya Produksi, Dan Pendapatan Usahatani Padi Sawah Di Desa Toinasa Kecamatan Pamona Barat. Jurnal Ilmu Sosial dan Ilmu Politik Vol. 10 (3): Hal 267-294.

Maria M.N. (2013). Analisis Kelayakan Finansial Kelapa Sawit Rakyat (Studi Kasus: Kecamatan Bagan Sinembah, Kabupaten Rokan Hilir, Provinsi Riau). Makalah Seminar. Medan..Fakultas Pertanian USU.

Maulidah1 S. dam D.E. Pratiwi. (2010) Analisis Kelayakan Finansial Usahatani Anggur Prabu Bestari. Jurnal AGRISE. Vol. (10)3: Hal. 1412-1425.

Mawardati. (2013). Analisis Faktor-faktor yang Mempengaruhi Pendapatan Usahatani Kentang Di Kabupaten Bener Meriah Provinsi Aceh. Jurnal Agrium. Vol. 10(2): Hal. 38-42.

Muin M. (2017). Pengaruh Faktor Produksi Terhadap Hasil Produksi Merica Di Desa Era Baru Kecamatan Tellulimpoe Kabupaten Sinjai. Jurnal Economix. Vol. 5 (1): Hal 2032014.

Munandar, A. (2016). Analisis Usaha Tani Kentang Di Desa Sembungan Kecamatan Kejajar Kabupaten Wonosobo Jawa Tengah. Jurnal SPATIAL Wahana Komunikasi Dan Informasi Geografi. Vol. 15(1): Hal. 34-29.

Munizar, Andi, dan Dance T. (2019). Analisis Pendapatan dan Kelayakan Usahatani Padi Sawah Sistem Hambur Benih Langsung di Desa Dolago Kecamatan Parigi Selatan Kabupaten Parigi Moutong. Agrotekbis. Vol. (7)1: Hal. 5158.

Nainggolan H.L. dan Johndikson A. (2016). Pengaruh Sosial Ekonomi Terhadap Pendapatan Petani Padi Sawah Dalam Sistem Integrasi Di Kecamatan Lintong Nihuta Kabupaten Hubang hasundutan. Jurnal Agrifo. Vol. 1(2): Hal. 43-70.

Napitupulu dan Marasi T.E. (2000). Pembangunan Pertanian dan Pengembangan Agroindustri. Jakarta: Pustaka Sinar Harapan.

Nguyen T.T., V.N. Hoang and B. Seo. (2012). Cost and Environmental Efficiency of Rice Farms in South Korea. Journal of Agricultural Economics. 43(4) : 369- 378.

Novianto F. W. dan Setyowati E. (2009). Analisis Produksi Padi Organik di Kabupaten Sragen. Jurnal Ekonomi Pembangunan. Vol. 10(2); Hal 267-288.

Nurmalina R., Sarianti T. dan Karyadi A. (2009). Studi Kelayakan Bisnis. Bogor. Departemen Agribisnis Fakultas Ekonomi dan Manajemen Institut Pertanian Bogor.

Palobo F., Herman M. dan Siska T. (2019). Analisis Kelayakan Usahatani Jagung Hibrida Pada Lahan Kering di Merauke Papua. Jurnal Sosial Ekonomi Pertanian dan Agribisnis (SEPA): Vol. (16)1: Hal 1- 10 .
Pratiwi C.A., Diah S.G. dan Istiqomah (2018). Analisis Ekonomi Usahatani Padi Dan Kelayakan Rumah Tangga Tani Di Desa Sambeng Kulon Kecamatan Kembaran Kabupaten Banyumas. Jurnal Sosial Ekomoi Pertanian (JSEP). Vol 11 (1): Hal 33-45.

Prayoga A. (2010). Produktivitas dan Efisiensi Teknis Usahatani Padi Organik Lahan Sawah. Jurnal Agro Ekonomi. Vol. (28) 1: Hal. 1-19.

Rustam W. (2014). Analisis Pendapatan Dan Kelayakan Usahatani Padi Sawah Di Desa Randomayang Kecamatan Bambalamotu Kabupaten Mamuju Utara. Jurnal Agrotekbis. Vol. 2 (6): Hal. 634-638.

Sajogyo dan Sumantoro M. (2005). Pemberdayaan Ekonomi Ralcyat Dalam Knncah Globalisasi. Bogor. Yayasan Sajogyo Utama.

Sari P. Nawang, Yahya S. Hilmi dan Windy S. Hariswanti. (2018). Kelayakan dan Nilai Tukar Petani Padi Organik di Kabupaten Sleman. Jurnal Sosial Ekonomi dan Kebijakan Pertanian. Vol. (7)2: Hal. 120-128.

Simanullang E.S dan Saragih F.H. (2017). Pengenalan Analisis Kelayakan Usaha Tani Padi Sawah di Desa Kebun Kelapa Kecamatan Secanggang Kabupaten Langkat. Vol. (23)1: Jurnal Pengabdian Kepada Masyarakat. Hal. 206-2010.

Soekartawi. (2011). Ilmu Usahatani dan Penelitian untuk Pengembangan Petani Kecil. Jakarta: UI-PRESS.

Sudrajat. (2018). Analisis Ketidakpastian dalam Memanfaatkan Lahan Pertanian di Desa Sukasari Kaler Kecamatan Argapura Majalengka. Majalah Geografi Indonesia. Vol. (32)1: Hal. 33-43.

Supartama, Made, Made Antara, dan Rustam Abd Rauf, 2013. Analisis Pendapatan dan Kelayakan Usaha Padi Sawah di Subak Baturiti Desa Balinggi Kecamatan Balinggi Kabupaten Parigi Moutong. Jurnal Agrotekbis. Vol. (1 )2 : Hal. 166-172.

Suratiyah, K. 2015. Ilmu Usahatani Edisi Revisi. Jakarta. Penebar Swadaya.

Suseno D. dan H. Suyatnal, (2007). Mewujudkan Kebijakan Pertanian yang Pro-Petani. Jurnal Ilmu Sosial dan Ilmu Politik. Vol. 10(3): Hal. 267-294.

Syarif K. (2011). Analisis Kelayakan Usaha Produk Minyak Aromatik Merek Flosh. Program Sarjana Alih Jenis Manajemen. Departemen Manajemen. Bogor. Fakultas Ekonomi dan Manajemen. Institut Pertanian Bogor.

Tahir A.G., D.H. Darwanto, J.H. Mulyo dan Jamhari. (2010). Analisis Efisiensi Produksi Sistem Usahatani Kedelai di Sulawesi Selatan. Jurnal Agro Ekonomi. Vol. (28)2: Hal.133 $-151$.

Umar H. (2005). Riset pemasaran dan Perilaku Konsumen. Jakarta. PT Gramedia Pustaka Utama. 